\title{
Impact of Laissez-Faire Leadership on Role Ambiguity and Role Conflict: Implications for Job Performance
}

\author{
${ }^{1}$ Mohammed Al-Malki, ${ }^{2}$ Wang Juan \\ 1,2 School of Economics, Central China Normal University, Wuhan, China
}

\begin{abstract}
The paper explores the ways to achieve superior job performance and cooperation among employees. The conceptual review suggests that leadership styles have an influence on role conflict and role ambiguity, which in turn impact job performance and cooperation. A questionnaire survey was prepared and conducted on the sample of Saudi Arabia companies' employees. The data was analysed using SPSS. The quantitative analysis consisted of descriptive statistics calculation, assumption testing, correlation analysis and regression analysis. The findings of the research suggest that role conflict and role ambiguity have a negative influence on increasing job performance. Another finding of the paper shows that increasing job performance positively impacts on job cooperation. Laissezfaire leadership impact on role ambiguity and role conflict is not significant. The findings of the research can be useful for the managers and leaders in terms of explaining the nature of role stressors and how they should be dealt with to increase the productivity of employees. The research paper builds on the theory of leadership and contributes to the leadershipperformance body of work.
\end{abstract}

Keywords: Laissez-faire leadership, Role ambiguity, Role conflict, Job performance, Cooperation

\section{Introduction}

Organizations are paying considerable attention to formulate organizational environment that prevents the cases of role stressors and foster better innovative team performance. Role stressors can be considered as role conflict and role ambiguity which negatively influences satisfaction of the job and employees' performance. What is the reason for some teams to perform better compared to other teams? A considerable amount of research papers in the field of leadership has strongly focused on finding the relevant answer to the given question. In other words, the influence of leaders on team performance has been investigated wide enough that it has resulted in the creation of the new argument and issues that need to be resolved empirically. The role of leaders is regarded as the critical tools for the team members. The reason is that leaders play a vital role in formulating collective norms, assisting the team members to face and resolve the challenges arisen in the team environment. The critical importance of leaders on team member resulted in the creation new ways based on which leaders can provide value for the members of the team.

The research is valuable as it digs into the concept of the difference of leadership and presents the fundamental understanding of its criticalness to job performance. This study will consider applicable ideas and result in exploring the optimal leadership facilitators conducive to superior job performance and cooperation. The main objectives of the study are to assess the influence of laissez-faire on role ambiguity and conflict and to assess the impact of role conflicts and role ambiguity on performance and cooperation. 


\section{Literature Review}

\subsection{Concept of Leadership}

Leaders are described as organizational efficiency influencers by inspiring the team members. Specifically, transactional type of leaders utilizes the system which is based on rewarding its followers thereby motivating them. Nevertheless, the motivation generated through reward lasts for a short period.

As several research papers suggest, transformational leadership helps to engage employees more than a transactional type of leadership (Keegan et al. 2004; Bass and Avolio J. 1990, Pearce 1981). In transactional leadership, employees are enabled to see themselves as a part of the team. Employees and followers who believe they are part of the organization are considered to be more committed to their job and serve for achieving the organizational goals. The quality of being able to inspire the followers, transformational leaders can make the followers put organizational goals over their own goals and interests. Such types of leaders are usually enthusiastic and energetic.

Peter Drucker (1989) mentioned that leadership is not created, taught and learned. Moreover, the literature shows that there has been a decline in the general belief which says that leadership characteristics are inherited from the birth. Thus, a great amount of attention was dedicated to understanding the number of characteristics that are found in leaders. According to the Trait theory of leadership, there have been some important studies which aimed to provide more valid results to describe the specific traits of leaders that can be learned and taught. According to the research by Locke (1991) drive, self-confidence, cognitive ability, honesty, and integrity are considered to be the most commonly observed traits of successful leaders. Recently, knowledge of context and desire to lead were added to the list of successful leadership traits. Majority of studies aimed to identify whether the above-mentioned traits were successful in a global context and universally accepted. In other words, it has been argued that whether traits of leaders can be applicable in the case of other cultural contexts. The research conducted by Bond and Smith (1996) identifies "Big Five" model of personality which can be used in the other cultural contexts. These traits include extroversion, emotional stability, readiness to accept challenges, agreeableness, and openness to experience.

Through the literature, it was concluded that most of the conflicts within the organization happen due to the role ambiguity and role conflict. The organizational theory proposes that when the top-management provides tasks to employees, the role ambiguity and role conflict occurs since employees cannot figure a clear picture of the goals (Keegan et al. 2004). Nonetheless, the empirical research on potential consequences of role conflict on the workers' performance still lacks. Referring to the Chain of Command Principle theory, it proposes that the top-level managers need to explain the tasks and responsibilities to their employees to avoid the conflicts and misinterpretations of the task-message (Datnow A. and Castellano, M. E. 2001). Similarly, the Unity Command Theory, in turn, suggests that it is more efficient to have only one team leader or coordinator in the organization to split, distribute and specify the tasks.

\subsection{Passive Laissez-Faire Leadership}

Passive laissez-faire leadership is based on trust. Passive laissez-faire leader renounces the responsibilities and avoids making decisions. Particularly, such leaders give their decisionmaking authority to managers and employees (Bass and Avolio, J. 2006). Such type of leadership is acceptable when the employees are experts in their field. Some research studies claim that laissez-faire leadership in the organization may lead to negative consequences and stress in employees. According to Yang et al. (2015), this type of leaders are passive leaders, 
who are not strategy-oriented which contradicts to the characteristics of the transformational and transactional leaders.

This type of leadership does not exercise strict control over their subordinates directly. Most of the people in the team are supposed to be highly experienced individuals. Thus, most of them do not need strict control and supervision. Moreover, such leaders do not provide continuous feedback for their employees, which is regarded as an essential element of successful teamwork. Due to the certain disadvantages provided by the leadership, team members may suffer from lack of communication, feedback for improvement and at the end, they may fail to meet the deadline for project completion.

\section{Research Model and Hypothesis}

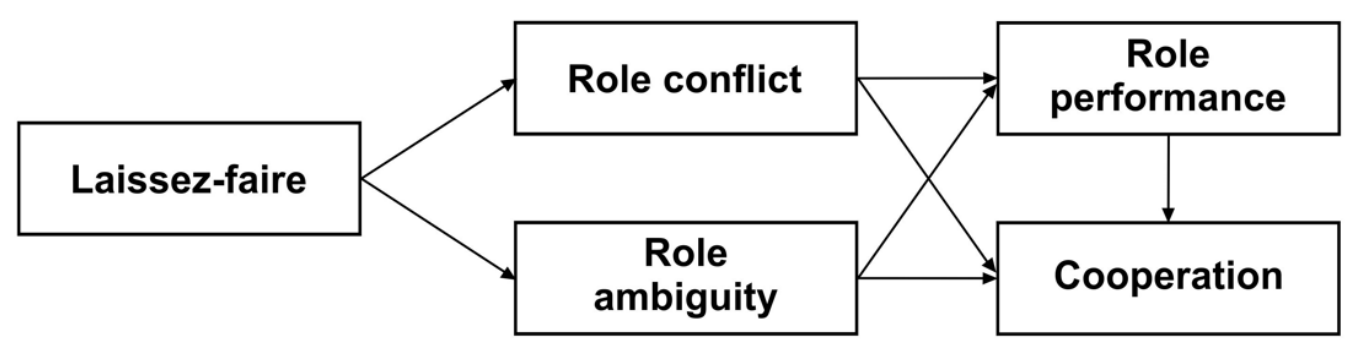

Figure 1

A research model encompassing relationships that capture the impact of leadership styles on cooperation and competition and ultimately team performance is yet to be derived. However, the process of deduction has already commenced. Drawing on the current theory, we propose that the model may consist of transformational, transactional, laissez-fair and ethical leadership which ultimately impacts team performance. Mediators are cooperation and competition within the team. Through further literature review and refinement in consulting with experts, a final research model will have been developed.

H1. Laissez-faire positively influences the role conflict

Since the laissez-faire leaders are passive, they are not enthusiastically concerned with resolving the issues of employees (Mach et al. 2010). So, in this context, employees are empowered with full authority on making important decisions (Van et al. 1981), which can result in the conflicts among the workers (Rhoades L. \& Eisenberger R. 2002; Samuel 2015). Thus, laissez-faire leadership is considered to positively influence the role conflict.

H2. Laissez-faire positively influences the role ambiguity

Although Laissez-faire leadership is more effective when the employees are experts in their field (Marginson D. \& Ogden, S. 2005), the subordinates can misunderstand the task and take wrong decisions leading to role ambiguity (Pearce et al. 2009). Therefore, utilization of lassies-faire type of leadership in the organization will contribute to the increase in the role ambiguity and misinterpretation of the roles in the organization (Roberts et al. 2010). 


\author{
Mohammed Al-Malki, Wang Juan \\ Impact of Laissez-faire Leadership on Role Ambiguity and Role Conflict: Implications for Job \\ Performance
}

H3. Role conflict negatively influences increasing job performance

Workers and subordinates who understand their job requirements and responsibilities are less engaged in role conflicts (House R. J. \& Rizzo J. R. 1972). Thus, the responsibilities of the employees are fully satisfied.

H4. Role ambiguity negatively influences the increase in the job performance When the instructions are given, and responsibilities of subordinates are explained, there is less ambiguity in the duties of the subordinates (Dubinsky, 1995; Marginson D. \& Ogden, S. 2005). So, when the ambiguity is low, the level of performance in employees is more likely to increase. Several studies including Samuel et al. (2015); and Skogstad et al. (2007) found out that role ambiguity should be prevented to increase the performance of the subordinates. Furthermore, employees are reported to perform more effectively when they are aware of their certain roles and responsibilities.

H5. Role conflict negatively influences the cooperation

Russo suggests that subordinates are more active in collaboration and cooperation when they are not engaged in any role conflicts (2012). Meanwhile, the role of the leader in this context is to resolve the role conflicts. Cooperation is conducive to the creation of positive work environment (Simon, 2014). When employees cooperate with each other, they work together and share knowledge, exchange their ideas and opinions with each other which is considered to be crucial for achieving organizational goals (Lowe et al. 2006; Bardes and Piccolo, 2010; Russo, 2012).

H6. The lower rate of Role ambiguity positively influences the cooperation When the rate of role ambiguity is low, the cooperation is closer (Marginson D. \& Ogden S. 2005). Subordinates who clearly understand their responsibilities and duties are highly engaged in collaboration with their peers. When there is a low rate of role ambiguity, employees feel more willing to work together and cooperate (Schyns, 2012). The findings of the several studies including Van et al. (1981) and Yang et al. (2015) found out that cooperation among employees is important for the achievement of organizational goals.

H7. Increased job performance positively influences job cooperation

This study proposes that cooperation and high job performance are positively related (Keegan et al. 2004). When there is increased job performance, job cooperation is also going to increase (Seiferd et al. 2013).

\title{
4. Methodology
}

The collection of the data was fulfilled in several stages. First of all, the survey was chosen as the method for collecting information. The leadership questionnaire developed by Steve W.J. When it comes to role conflict and ambiguity, the proposed Bray scale was utilized. Even though it was tested mostly in sport, the questionnaire was adopted for business research according to the suggestions and remarks of Eys et al. (2001). The latterly considered role ambiguity is a composite variable. Taking the work of William and Anderson (1991) as the basis for evaluation of the job performance of employees, 7-item-scale was adopted. Meanwhile, job cooperation was measured by a 5-point-scale. Kozlowski and Daniel R. Ilgen et al. seem to be the most appropriate for the current study.

Table 1: Concept definition 
Mohammed Al-Malki, Wang Juan

Impact of Laissez-faire Leadership on Role Ambiguity and Role Conflict: Implications for Job

Performance

\begin{tabular}{|l|l|}
\hline Laissez-Faire & \multicolumn{1}{|c|}{ Definition } \\
\hline Role conflict & $\begin{array}{l}\text { This type of leadership is also known as } \\
\text { delegative leadership, where leader allows } \\
\text { his/her subordinates to make decisions by } \\
\text { offering them freedom (Chen et al., 2005; } \\
\text { Day, 2001) }\end{array}$ \\
\hline Role ambiguity & $\begin{array}{l}\text { A situation where a person is required to } \\
\text { undertake multiple roles (Hauge et al. 2011) }\end{array}$ \\
\hline Job performance & $\begin{array}{l}\text { A situation where a person is unclear and } \\
\text { uncertain about his/her roles within the } \\
\text { organization (Einarsen, 2008) }\end{array}$ \\
\hline Cooperation & $\begin{array}{l}\text { Performance of employee which focuses on } \\
\text { an assessment of his/her duties well (Mach } \\
\text { et al., 2010) }\end{array}$ \\
\hline $\begin{array}{l}\text { The process where employees collaborate } \\
\text { and cooperate with each other by sharing } \\
\text { knowledge, experience, and opinions for the } \\
\text { accomplishment and achievement of } \\
\text { objectives (Larson, 2012). }\end{array}$ \\
\hline
\end{tabular}

Testing of face validity was the main aim of the third step of data collection. Nonetheless, to avoid further errors and examine the proposed questionnaire, the pilot study was done within the company of 18 employees. The invitation for survey participation was sent to through email to the representatives of different companies. Moreover, innovations in technology simplified the process of data collection. The survey questions were placed on SurveyMonkey. The link provided in the email led directly to the questionnaire. The instructions were included both in the questionnaire and email. Moreover, the participants could contact the researchers in case of any problems. As the main goal is to investigate the impact of leadership style on job performance and cooperation through role ambiguity and role conflict, it was essential to receive the response, not from relevant employees. The survey was conducted in large companies. The targeted population consisted of company employees. Furthermore, the whole population was also divided by gender and work experience, and other demographic criteria. The questionnaire was sent to 230 people with 166 respondents taken as a sample for analysis, as all the missing values were eliminated.

\section{Results}

The data was analysed using SPSS. The quantitative analysis consisted of descriptive statistics calculation, assumption testing, correlation analysis and regression analysis. The measurement tool validity and reliability were confirmed statistically. Kolmogorov-Smirnov, Shapiro-Wilk tests and Q-Q plots were used to confirm the normality of the data set. As all assumptions were confirmed regression analysis was performed.

The linear regression is used to prove the existence of the relationship between role ambiguity, role conflict, and job performance. The regression analysis was divided into several stages. Firstly, the relationship between role conflict and laissez-faire took place. Model summary of the table 2 states that very small percentage of variability in role conflict is accounted for by laissez-faire $\left(R^{\wedge} 2=0.5 \%\right)$. Meanwhile Adjusted $R^{\wedge} 2$ has a negative sign. The significance of F-test above accepted 0.05 .

Nonetheless, the relationship between the above-mentioned variables was considered. Thus, laissez-faire is negatively related to role conflict $(\beta=-0.02, p>0.05)$. Laissez-faire has a positive influence on role conflict. 
Mohammed Al-Malki, Wang Juan

Impact of Laissez-faire Leadership on Role Ambiguity and Role Conflict: Implications for Job

Performance

Table 2: Descriptive Statistics

\begin{tabular}{|l|l|l|l|l|l|l|l|l|l|}
\hline & $\mathrm{N}$ & $\begin{array}{c}\text { Minimu } \\
\mathrm{m}\end{array}$ & $\begin{array}{c}\text { Maxim } \\
\text { um }\end{array}$ & Mean & $\begin{array}{c}\text { Std. } \\
\text { Deviatio } \\
\mathrm{n}\end{array}$ & \multicolumn{2}{|c|}{ Skewness } & \multicolumn{2}{c|}{ Kurtosis } \\
\cline { 2 - 11 } & $\begin{array}{c}\text { Statisti } \\
\mathrm{C}\end{array}$ & $\begin{array}{c}\text { Statisti } \\
\mathrm{C}\end{array}$ & $\begin{array}{c}\text { Statist } \\
\text { ic }\end{array}$ & $\begin{array}{c}\text { Statisti } \\
\mathrm{C}\end{array}$ & Statistic & $\begin{array}{c}\text { Statist } \\
\text { ic }\end{array}$ & $\begin{array}{c}\text { Std. } \\
\text { Error }\end{array}$ & $\begin{array}{c}\text { Statist } \\
\text { ic }\end{array}$ & $\begin{array}{c}\text { Std. } \\
\text { Error }\end{array}$ \\
\hline Role conflict & 166 & 1.30 & 5.00 & 3.2711 & .63717 & -.083 & .264 & .832 & .523 \\
\hline $\begin{array}{l}\text { Role } \\
\text { ambiguity }\end{array}$ & 166 & 2.00 & 4.71 & 3.3253 & .57460 & -.169 & .264 & -.121 & .523 \\
\hline $\begin{array}{l}\text { Job } \\
\text { performance }\end{array}$ & 166 & 2.00 & 4.71 & 2.9174 & .60737 & .926 & .264 & .411 & .523 \\
\hline Cooperation & 166 & 1.80 & 5.00 & 3.7590 & .79065 & -.010 & .264 & -.795 & .523 \\
\hline Laissez-faire & 166 & 2.00 & 12.00 & 6.9880 & 2.25504 & -.057 & .264 & -.510 & .523 \\
\hline $\begin{array}{l}\text { Valid N } \\
\text { (listwise) }\end{array}$ & 166 & & & & & & & & \\
\hline
\end{tabular}

Table 3: Role conflict model summary

\begin{tabular}{|c|c|c|c|c|c|c|c|}
\hline Model & $\mathrm{R}$ & R Square & $\begin{array}{l}\text { Adjust } \\
\text { Square }\end{array}$ & ed & $\begin{array}{l}\text { Std. The error } \\
\text { of the Estimate }\end{array}$ & & \\
\hline 1 & $.072^{a}$ & .005 & -.007 & & .63945 & & \\
\hline a. Pred & tors: (Cons & cant), Laiss & $z$-faire & & & & \\
\hline Model & & \begin{tabular}{l|l} 
& Sum \\
Squares
\end{tabular} & of & $\mathrm{df}$ & Mean Square & $F$ & Sig. \\
\hline 1 & Regression & .170 & & 1 & .170 & .417 & $.001^{b}$ \\
\hline & Residual & 33.120 & & 165 & .409 & & \\
\hline & Total & 33.291 & & 166 & & & \\
\hline
\end{tabular}

Table 4: Role conflict Coefficients ${ }^{a}$

\begin{tabular}{|c|c|c|c|c|c|c|}
\hline \multicolumn{2}{|c|}{ Model } & \multicolumn{2}{|c|}{ Unstandardized Coefficients } & \multirow{2}{*}{$\begin{array}{l}\text { Standardized } \\
\text { Coefficients } \\
\text { Beta }\end{array}$} & \multirow[t]{2}{*}{$\mathrm{t}$} & \multirow[t]{2}{*}{ Sig. } \\
\hline & & $B$ & Std. Error & & & \\
\hline \multirow[t]{2}{*}{1} & (Constant) & 3.412 & .230 & & 14.849 & .000 \\
\hline & Laissez-faire & -.020 & .031 & -.072 & -.646 & .001 \\
\hline
\end{tabular}

Further, the relationship between laissez-faire and role ambiguity were examined. Notably, only $1 \%$ of role ambiguity can be predicted by non-intervention style of leadership. The same as for role conflict, adjusted $R^{\wedge} 2$ is negative. F-test has quite a low $p$-value. Despite that $p$ value is higher than 0.05 , the sign of their relationship is negative. Judging from this, laissezfair has a negative impact on the role ambiguity.

\subsection{Laissez-Faire Has a Positive Impact on Role Ambiguity}

Table 5: Role ambiguity model summary 


\begin{tabular}{|l|l|l|c|c|}
\hline Model & $\mathrm{R}$ & $\mathrm{R}$ Square & $\begin{array}{c}\text { Adjusted R } \\
\text { Square }\end{array}$ & $\begin{array}{c}\text { Std. Error of the } \\
\text { Estimate }\end{array}$ \\
\hline 1 & $.102^{\mathrm{a}}$ & .010 & -.002 & .57514 \\
\hline
\end{tabular}

a. Predictors: (Constant), Laissez-faire

Table 6: Role ambiguity ANOVAa

\begin{tabular}{|l|l|l|l|l|l|l|}
\hline \multicolumn{2}{|c|}{ Model } & \multicolumn{1}{c|}{$\begin{array}{c}\text { Sum of } \\
\text { Squares }\end{array}$} & $\mathrm{df}$ & Mean Square & $\mathrm{F}$ & Sig. \\
\hline \multirow{2}{*}{1} & Regression & .281 & 1 & .281 & .848 & $.360^{\mathrm{b}}$ \\
\cline { 2 - 7 } & Residual & 26.793 & 165 & .331 & & \\
\cline { 2 - 7 } & Total & 27.074 & 166 & & & \\
\hline
\end{tabular}

a. Dependent Variable: Role Ambiguity

b. Predictors: (Constant), Laissez-faire

Table 7: Role ambiguity Coefficients ${ }^{a}$

\begin{tabular}{|l|l|l|l|l|l|l|}
\hline \multicolumn{2}{|l|}{ Model } & \multicolumn{2}{|l|}{ Unstandardized Coefficients } & $\begin{array}{l}\text { Standardized } \\
\text { Coefficients }\end{array}$ & \multirow{2}{*}{ Sig. } \\
\cline { 3 - 5 } \multicolumn{2}{|l|}{} & B & Std. Error & Beta & \\
\hline \multirow{2}{*}{1} & (Constant) & 3.507 & .207 & & 16.965 & .000 \\
\cline { 2 - 6 } & Laissez-faire & -.026 & .028 & -.102 & -.921 & .360 \\
\hline
\end{tabular}

a. Dependent Variable: Role Ambiguity

As the next step, the influence of the role conflict on the job performance was tested. In this regression analysis, role conflict was taken as a predictor of job performance. The results of table 10 show that $0.7 \%$ of job performance is accounted by the chosen regressor. Adjusted $R^{2}$ has negative direction, while $\mathrm{R}=0.08$. $\mathrm{P}$-value of F-test is 0.5 , shows that it is above the accepted significance level. Sum of squares and mean square of the current regression are identical and equal to 0.2 . The analysis of the connection between the variables indicates that role conflict positively impacts on the job performance, however, due to $p$-value $>0.05$, this relationship can be ignored.

\subsection{Role Conflict Has a Negative Influence on Increasing Job Performance}

Results show that role conflict negatively impacts the job performance.

Table 8: Job Performance-Role conflict model summary

\begin{tabular}{|c|c|c|c|c|}
\hline Model & $\mathrm{R}$ & R Square & $\begin{array}{l}\text { Adjusted } \\
\text { Square }\end{array}$ & $\begin{array}{l}\text { RStd. Error of the } \\
\text { Estimate }\end{array}$ \\
\hline 1 & $.084^{a}$ & .007 & -.005 & .60896 \\
\hline \multicolumn{5}{|c|}{ a. Predictors: (Constant), Role conflict } \\
\hline
\end{tabular}

Table 9: Job Performance-Role conflict ANOVA

\begin{tabular}{lllllll}
\hline Model & & Sum of Squares & Df & Mean Square & $\mathrm{F}$ & Sig. \\
\hline \multirow{3}{*}{1} & Regression & .212 & 1 & .212 & .573 & $.001^{\mathrm{b}}$ \\
& Residual & 30.037 & 165 & .371 & & \\
& Total & 30.250 & 166 & & & \\
\hline
\end{tabular}


a. Dependent Variable: Job performance

b. Predictors: (Constant), Role conflict

Table 10: Job Performance-Role conflict Coefficients

\begin{tabular}{|c|c|c|c|c|c|c|}
\hline \multirow[t]{2}{*}{ Model } & & \multicolumn{2}{|c|}{ Unstandardized Coefficients } & \multirow{2}{*}{$\begin{array}{l}\text { Standardized } \\
\text { Coefficients } \\
\text { Beta }\end{array}$} & \multirow[t]{2}{*}{$\mathrm{t}$} & \multirow[t]{2}{*}{ Sig. } \\
\hline & & B & Std. Error & & & \\
\hline \multirow{2}{*}{1} & (Constant) & 2.656 & .352 & & 7.553 & .000 \\
\hline & Role conflict & -.080 & .106 & .084 & .757 & .001 \\
\hline
\end{tabular}

a. Dependent Variable: Job performance

When it comes to the relationship between job performance and role ambiguity, the H_O stated that role ambiguity positively predicts the job performance. In order to approve or reject it, the following steps were undertaken. The same as with previous relationship, the main indicators of this relationship is establishing the value of beta and its significance. The table 16 shows that the constant beta is equal to 1.16 . Meanwhile, a beta of the relationship between role ambiguity and job performance is positive $(\beta=0.53)$. In addition to it, the significance is very high, below 0.001 . This shows the strength of the relationship between the variables. F-test also has high significance level ( $p$-value $<0.001)$. And the accountability of job performance by role ambiguity is $25 \%$, meaning that almost one-quarter of the regress and can be predicted by role ambiguity.

\subsection{Role Ambiguity Has a Negative Influence in Increasing the Job Performance}

Table 11: Job Performance-Role ambiguity model summary

\begin{tabular}{ccccc}
\hline Model & $\mathrm{R}$ & $\mathrm{R}$ Square & $\begin{array}{c}\text { Adjusted R } \\
\text { Square }\end{array}$ & $\begin{array}{c}\text { Std. Error of the } \\
\text { Estimate }\end{array}$ \\
1 & $.501^{\mathrm{a}}$ & .251 & .242 & .52894 \\
\hline
\end{tabular}

a. Predictors: (Constant), Role Ambiguity

Table 12: Job Performance-Role ambiguity ANOVA ${ }^{a}$

\begin{tabular}{ccccccl}
\hline \multirow{4}{*}{1} & Model & Sum of Squares & $\mathrm{df}$ & Mean Square & $\mathrm{F}$ & Sig. \\
\cline { 2 - 6 } 1 & Regression & 7.588 & 1 & 7.588 & 27.120 & $.000^{\mathrm{b}}$ \\
& Residual & 22.662 & 165 & .280 & & \\
& Total & 30.250 & 166 & & & \\
\hline
\end{tabular}

a. Dependent Variable: Job performance

b. Predictors: (Constant), Role Ambiguity

Table 13: Job Performance-Role ambiguity Coefficients ${ }^{\mathrm{a}}$

\begin{tabular}{|l|l|l|l|l|l|l|}
\hline \multicolumn{2}{|l|}{ Model } & \multicolumn{2}{l|}{ Unstandardized Coefficients } & $\begin{array}{l}\text { Standardized } \\
\text { Coefficients }\end{array}$ & t & Sig. \\
\cline { 3 - 5 } \multicolumn{2}{l|}{} & B & Std. Error & Beta & & \\
\hline 1 & (Constant) & 1.157 & .343 & & 3.373 & .001 \\
\cline { 2 - 5 } & Role Ambiguity &.-529 & .102 & .501 & 5.208 & .000 \\
\hline a. Dependent Variable: Job performance \\
\hline
\end{tabular}


As the next step, the influence of various independent variables on the cooperation was tested. It was predicted that role conflict should have a negative effect on the level of cooperation among employees. Referring to table 18 , adjusted $R^{\wedge} 2$ is -0.01 , while $R$ has a positive sign and equal to 0.02 . F test illustrates how good the chosen model fits the collected data. However, the significance of F-test is above 0.05 . Regardless that $R^{\wedge} 2$ is too small, the relationship between role conflict and cooperation between co-workers was tested. Based on the results of table 20 , role conflict negatively predicts the level of cooperation, which is the same as the hypothesized assumption. Nonetheless, the significance of this relationship should be taken into consideration.

\subsection{Role Conflict Has a Negative Influence in Increasing the Cooperation}

Table 14: Cooperation-Role conflict model summary

\begin{tabular}{lllll}
\hline Model & $\mathrm{R}$ & R Square & $\begin{array}{l}\text { Adjusted } \\
\text { Square }\end{array}$ & $\begin{array}{l}\text { RStd. Error of the } \\
\text { Estimate }\end{array}$ \\
\hline 1 & $.018^{\mathrm{a}}$ & .000 & -.012 & .79538
\end{tabular}

a. Predictors: (Constant), Role conflict

Table 15: Cooperation-Role conflict ANOVA

\begin{tabular}{lllllll}
\hline Model & & Sum of Squares & $\mathrm{df}$ & Mean Square & $\mathrm{F}$ & Sig. \\
\hline \multirow{2}{*}{1} & Regression & .017 & 1 & .017 & .027 & $.869^{\mathrm{b}}$ \\
& Residual & 51.243 & 165 & .633 & & \\
& Total & 51.261 & 166 & & & \\
\hline
\end{tabular}

a. Dependent Variable: cooperation

b. Predictors: (Constant), Role conflict

Table 16: Cooperation-Role conflict Coefficients ${ }^{a}$

\begin{tabular}{|c|c|c|c|c|c|c|}
\hline \multirow[t]{2}{*}{ Model } & & \multicolumn{2}{|c|}{ Unstandardized Coefficients } & \multirow{2}{*}{$\begin{array}{l}\text { Standardized } \\
\text { Coefficients } \\
\text { Beta }\end{array}$} & \multirow[t]{2}{*}{$\mathrm{T}$} & \multirow[t]{2}{*}{ Sig. } \\
\hline & & B & Std. Error & & & \\
\hline 1 & $\begin{array}{l}\text { (Constant) } \\
\text { Role conflict }\end{array}$ & $\begin{array}{l}3.834 \\
-.023\end{array}$ & $\begin{array}{l}.459 \\
.138\end{array}$ & -.018 & $\begin{array}{l}8.346 \\
-.165\end{array}$ & $\begin{array}{l}.000 \\
.869\end{array}$ \\
\hline
\end{tabular}

a. Dependent Variable: cooperation

Imitating the previous procedure, the influence of role ambiguity on the level of cooperation in the companies was examined. Standard errors of the estimate together with R are below 1 . $R^{\wedge} 2$ in table 22 is 0.03 , showing that $3 \%$ of the cooperation is accounted for. Sum of squares and mean square is similar and equal to 1.52 . While $F$ test of 2.48 has low significance. Beta coefficient of the relationship between role ambiguity and cooperation has a positive sign ( $\beta=$ $0.24, \mathrm{p}<0.05)$.

\subsection{Role Ambiguity Has a Negative Influence in Increasing the Cooperation}

Table 17: Cooperation-Role ambiguity model summary

\begin{tabular}{lllll}
\hline Model & $\mathrm{R}$ & R Square & $\begin{array}{l}\text { Adjusted } \\
\text { Square }\end{array}$ & $\begin{array}{l}\text { RStd. Error of the } \\
\text { Estimate }\end{array}$ \\
\hline 1 & $.172^{\mathrm{a}}$ & .030 & .018 & .78361
\end{tabular}

a. Predictors: (Constant), Role Ambiguity 
Mohammed Al-Malki, Wang Juan

Impact of Laissez-faire Leadership on Role Ambiguity and Role Conflict: Implications for Job

Performance

Table 18: Cooperation-Role ambiguity ANOVA

\begin{tabular}{lllllll}
\hline Model & & Sum of Squares & Df & Mean Square & F & Sig. \\
\hline \multirow{2}{*}{1} & Regression & 1.523 & 1 & 1.523 & 2.479 & $.119^{\mathrm{b}}$ \\
& Residual & 49.738 & 165 & .614 & & \\
& Total & 51.261 & 166 & & &
\end{tabular}

a. Dependent Variable: cooperation

b. Predictors: (Constant), Role Ambiguity

Table 19: Cooperation-Role ambiguity Coefficients ${ }^{a}$

\begin{tabular}{|c|c|c|c|c|c|c|}
\hline \multirow[t]{2}{*}{ Model } & & \multicolumn{2}{|c|}{ Unstandardized Coefficients } & \multirow{2}{*}{$\begin{array}{l}\text { Standardized } \\
\text { Coefficients } \\
\text { Beta }\end{array}$} & \multirow[t]{2}{*}{$\mathrm{t}$} & \multirow[t]{2}{*}{ Sig. } \\
\hline & & B & Std. Error & & & \\
\hline \multirow{2}{*}{1} & (Constant) & 2.970 & .508 & & 5.846 & .000 \\
\hline & Role Ambiguity & .237 & .151 & .172 & 1.575 & .119 \\
\hline
\end{tabular}

a. Dependent Variable: cooperation

Finally, the interaction between job performance and cooperation was tested by the help of linear regression. The table 26 shows that $17 \%$ of job cooperation are accounted for by job performance. Adjusted $\mathrm{R}^{\wedge} 2$ is slightly less than $\mathrm{R}^{\wedge} 2(0.16)$. F-test equalled to 16.58 has a high significance that is less than 0.001 . Notably, that relationship between job performance and cooperation also has the $\mathrm{p}$-value $<0.001$, indicating that their relationship is significant. Moreover, positive $\beta$-value of 0.54 shows that increased job performance has a positive influence on job cooperation. Based on this proof, the null hypothesis can be rejected. The constant $\beta$ is equal to 2.2 .

\subsection{Increased Job Performance Has a Positive Influence on Job Cooperation}

Table 20: Job performance-Cooperation model summary

\begin{tabular}{lllll}
\hline Model & $\mathrm{R}$ & R Square & $\begin{array}{l}\text { Adjusted } \\
\text { Square }\end{array}$ & $\begin{array}{l}\text { RStd. Error of the } \\
\text { Estimate }\end{array}$ \\
\hline 1 & $.412^{\mathrm{a}}$ & .170 & .160 & .72477
\end{tabular}

a. Predictors: (Constant), Job performance

Table 21: Job performance-Cooperation ANOVA ${ }^{a}$

\begin{tabular}{lllllll}
\hline Model & & Sum of Squares & Df & Mean Square & F & Sig. \\
\hline & Regression & 8.712 & 1 & 8.712 & 16.584 & $.000^{\mathrm{b}}$ \\
1 & Residual & 42.549 & 165 & .525 & & \\
& Total & 51.261 & 166 & & & \\
\multicolumn{7}{l}{ a. Dependent Variable: cooperation } \\
b. Predictors: (Constant), Job performance
\end{tabular}

Table 22: Job Performance-Cooperation Coefficients ${ }^{a}$

\begin{tabular}{|c|c|c|c|c|c|c|}
\hline \multirow{2}{*}{\multicolumn{2}{|c|}{ Model }} & \multicolumn{2}{|c|}{ Unstandardized Coefficients } & \multirow{2}{*}{$\begin{array}{l}\text { Standardized } \\
\text { Coefficients } \\
\text { Beta } \\
\end{array}$} & \multirow[t]{2}{*}{$\mathrm{T}$} & \multirow[t]{2}{*}{ Sig. } \\
\hline & & B & Std. Error & & & \\
\hline \multirow{2}{*}{1} & (Constant) & 2.193 & .393 & & 5.587 & .000 \\
\hline & Job performance & .537 & .132 & .412 & 4.072 & .000 \\
\hline
\end{tabular}




\section{Discussion of the findings}

\subsection{Hypotheses Analyses}

The findings of the research suggest that managing role stressors as role ambiguity have positive influence to increase job performance. Another finding of the paper shows that increasing job performance positively impacts on job cooperation. Thus, the findings of the research can be useful for the managers and leaders in terms of explaining the nature of role stressors and how they should be dealt with to increase the productivity of employees.

H1. Laissez-faire positively influences the role conflict

Laissez-faire leadership is the least effective type of leadership styles. The teams under the control laissez-faire leaders have the freedom to take responsibility for their actions. In other words, leaders do not intervene with the daily tasks of their employees and subordinates. Many studies found out that the current type of leadership was the least productive. Although not significant, the results of the current investigation show that laissez-faire positively influences the role conflict and it is statistically significant. The findings of this study are consistent with the findings of several studies (Barrow, 2004; Barsade and Gibson, 2007).

H2. Laissez-faire positively influences the role ambiguity

Alongside with the results of the previous hypothesis, the laissez-faire type of leadership encourages the role ambiguity among the subordinates. The result of the current studies showed that there is a positive relationship between laissez-faire leadership and role ambiguity, which is not statistically significant. The findings of the current study are not directed to discourage the usage of the laissez-faire type of leadership. It is clear that this type of leader has various advantages and the subordinates under laissez-faire leaders can be quite successful provided that they are smart and skilful. It is also important to mention that final decision making is strongly dependent on the laissez-faire leaders although they provide complete power and freedom to their subordinates in accomplishments of daily tasks. However, despite the number of advantages of laissez-faire type of leadership. Thus, it can be concluded that there is no positive influence of laissez-faire leadership style on encouraging role ambiguity.

H3. Role conflict negatively influences increasing job performance

Another aim of the current study is to identify the relationship between role conflict and job performance. The study proposed the following hypothesis stating that resolving role conflict has a positive influence on increasing job performance. The findings of our study show that resolving role conflict has a positive influence in increasing the job performance and they are statistically significant. However, the findings are not significant. The findings of previous papers which focused on potential implications of resolving role conflict reported that it has a positive influence on increasing job performance (Mach et al. 2010; Koustelios et al., 2004)

H4. Role ambiguity negatively influences the increase in the job performance One of the proposed hypotheses of the study focused on studying the influence of role ambiguity and job performance. Precisely, resolving role ambiguity has a positive impact on increasing the job performance. The findings of paper show that there is a statistically significant and positive-negative relationship between resolving role ambiguity and increased job performance. The findings of the study are similar to the findings of the previous scholars including Bardes and Piccolo (2010) and Stajkovic A. D., \& Luthans, F. (1998). Goal setting theory can be used to support and explain the relationship between role ambiguity and job performance. According to the goal-setting theory, subordinates are more likely to show high levels of commitment and responsibility when they are informed about the goals they have to achieve. 


\author{
Mohammed Al-Malki, Wang Juan \\ Impact of Laissez-faire Leadership on Role Ambiguity and Role Conflict: Implications for Job \\ Performance
}

H5. Role conflict negatively influences the cooperation

The research proposed to study the relationship between the role conflict and cooperation. The conflict is regarded as one of the major obstacles which can negatively influence the productivity of the employees. The role of the leader is important in resolving conflicts among the employees. The findings of the study show that there is a negative relationship between role conflict and cooperation. Therefore, the study found no significant relationship between these variables.

H6. The lower rate of Role ambiguity positively influences the cooperation The study proposed that the resolving role ambiguity has a positive influence in increasing the cooperation. However, the findings of the study showed that there is a relationship between resolving role ambiguity and increasing job corporation. However, this relationship is found to be not significant. Previous studies conducted in the field found that resolving role ambiguity has a positive influence on increasing job satisfaction. However, the influence of role ambiguity on job cooperation was not analyzed by many scholars. Transformational leaders provide clear and concise the instruction for each team member so that team members will not have any misunderstanding and conflicts regarding their roles (Barrow, 1977).

H7. Increased job performance positively influences job cooperation

The current study has proposed that increased job performance has a positive influence on job cooperation. Analysis of collected data revealed that there is a significant positive relationship between increased job performance and job cooperation. The find ings of the current paper are consistent with the findings of the various studies (Combs, 1999; Bontis, 1995). Increased job cooperation is linked to increased levels of job satisfaction among the employees. It has been reported that satisfied and happy employees are more likely to cooperate with their colleagues by sharing and exchanging knowledge. In this regard, it can be mentioned that the majority of the studies focused on finding the relationship job satisfaction and job performance (Larson, 2012; Watson, 2002; Mumford, 2000).

\title{
6.2 Practical Implications
}

The study provides various practical implications that can be useful and valuable for managers, leaders, middle and top level managers who come across the challenges of working in teams. The study offers innovative insights on how different types of leaders cope with role ambiguity and role conflict in increasing job performance. The study takes a specific approach to analyze the influence of laissez-faire type of leadership in resolving role ambiguity and role conflict in order to increase job performance. Increasing job performance is believed to have a significant influence on job cooperation which can be seen from the results of the current study. It is critical for the leaders to bear in mind of potential side effects of role ambiguity and role conflict which is detrimental to the process of employees' productivity and effectiveness. A clear understanding of employee needs and clear picture of potential negative effects of role ambiguity and role conflict can encourage leaders to take effective measures to create a better organizational environment where employees can work upon their best potential. The increased job performance is found to positively impact increase of innovative capabilities of the employees and job satisfaction. If undertaken effectively, leaders will tend to transform the companies to be the more inclusive place to work through active and dynamic processes which will be accomplished by overcoming job stressors such as role conflict and role ambiguity. Leaders can enable each employee of the organization to be seen as a leader in a particular area which they are good at. This study has focused on overcoming jobs stressors such as role conflict and role ambiguity in the context of teams and some important practical implications for the managers and executives can be put forward. The first implication involves the basic structure of the teamwork. Generally, the members of the team are different regarding the roles which they undertake due to the difference in their skills and 


\author{
Mohammed Al-Malki, Wang Juan \\ Impact of Laissez-faire Leadership on Role Ambiguity and Role Conflict: Implications for Job \\ Performance
}

capabilities. Thus, it is important that group of employees within a team should be properly educated about the importance of teamwork not as an only short-term project. Instead, the role of teamwork should be emphasized in a sense which significantly impacts the value of the organization. Therefore, overcoming role conflict and role ambiguity is believed to be positive for the team effectiveness which in turn increases the strategic value of the business. Another important implication of the current study can be explained in terms of the creating and sustaining leadership strategy. Leadership is believed to be subject to strategic planning. Leadership is found to play an important role in providing common direction and commitment. The collective work strategy is strongly related to the pursuit of successful leadership style. The strategies followed by the leaders should not be only relevant for the usage among team members but for each member of the organization.

\title{
7. Conclusion
}

The current research proposes the conceptual framework which can be used to analyse the influence of laissez-faire leadership in response to role stressors, such as role conflict and role ambiguity which are directly related to job performance and cooperation. Furthermore, future research should consider the influence of another role stressor known as work overload and its consequent impact on employees' performance and job satisfaction. Additionally, an impact of various leadership styles, such as transactional and transformational leadership should be considered. In a highly competitive world, it is crucial for the organizations to be aware of the potential impact of role stressors. As it can be seen from the review of the previous literature and findings of the current research, role stressors such as role ambiguity and role conflict are found as the most important source of job dissatisfaction and job performance. Understanding the nature of role stressors and potential sources which may cause them to will help organizations to take control of managing role stressors. Managing role stressors and controlling them will enable organizations to increase the productivity and job satisfaction of employees. Moreover, leaders and their management styles also play a critical role in managing role conflicts and finding main sources of role stressors. The majority of role stressors such as role ambiguity arise as a result of lack of quality of feedback and suggestions provided by leaders. Therefore more attention from practice and academia should be paid to job performance, roles and leadership should themes as they relate to one another.

\section{References}

- Achrol, R., and Stern, L. (1988). Environmental determinants of decision-making uncertainty in marketing channels. Journal of Marketing Research, 25(1), 36-50.Crossref

- Anderson, E., and Jap, S. D. (2005). The dark side of close relationships. MITSloan Management Review, 46(3), 75-82.

- Avolio, B. C., Walumbawa F. O., and Weber, T. J. (2009). Leadership: Current theories, research, and future directions. Annual Review of Psychology, 60, 421-449. Crossref

- Balducci, C., Cecchin, M. and Fraccaroli, F. (2012). The impact of role stressors on workplace bullying in both victims and perpetrators, controlling for personal vulnerability factors: A longitudinal analysis. Work and Stress, 26(3), pp.195-212. Crossref

- Bardes, M., \& Piccolo, R. F. (2010). Goal setting as an antecedent of destructive leader behaviors. When leadership goes wrong: Destructive leadership, mistakes and ethical failures, 3-22.

- Barrow, J. C. (1977). The variables of leadership: A review and conceptual framework. Academy of Management Review, 2(2), 231-251, Crossref

- Barsade, S.G. and Gibson, D.E. (2007), "Why does affect matter in organizations?", Academy of Management Perspectives, Vol. 21, February, pp. 36-59. Crossref

- Bass, B. M. (1990). From transactional to transformational leadership: Learning to share the vision. Organizational dynamics, 18(3), 19-31. 
- Bettencourt, L.A. and Brown, S.W. (2003). Role stressors and customer-oriented boundary-spanning behaviors in service organizations. Journal of the academy of Marketing Science, 31(4), pp.394 Crossref

- Chen, H., Beck, S., and Amos, L. (2005). Leadership styles and nursing faculty job satisfaction in Taiwan. Journal of Nursing Scholarship, 37, 374-380. Crossref

- Clark, L. A. (2007). Assessment and diagnosis of personality disorder: Perennial issues and an emerging reconceptualization. Annual Review of Psychology, 58,227-257. Crossref

- Cooper, Arnold C. and Dunkelberg, William C. and Woo, Carolyn Y., Entrepreneurs' Perceived Chances for Success (1988). Journal of Business Venturing, Vol. 3, Issue 2, p. 97-108 1988. Crossref

- Daniels, K. and Bailey, A., 1999. Strategy development processes and participation in decision making: predictors of role stressors and job satisfaction. Journal of applied management studies, 8(1), p.27.

- Datnow A. and Castellano, M. E. (2001). Managing and guiding school reform: Leadership in success for all schools. Educational Administration Quarterly, 37(2), 219-249. Crossref

- Drucker, P. F. (1989). What business can learn from nonprofits? Harvard business review, 67(4), 88-93.

- Dubinsky, A. J., Yammarino, F. J., Jolson, M. A., and Spangler, W. D. (1995). Transformational leadership: An initial investigation in sales management. Journal of Personal Selling and Sales Management, 15(2), 17-31.

- Gottfried, A. E., Gottfried, A. W., Reichard, R. J., Guerin, D. W., Oliver, P. H. and Riggio, R. E. (2011). Motivational roots of leadership: A longitudinal study from childhood through adulthood. The Leadership Quarterly, 22(3), 510-519, Crossref

- Hannah, S. T., Uhl-Bien, M., Avolio, B. J. and Cavarretta, F. (2009). A framework for leadership in extreme contexts. The Leadership Quarterly, 20, 897-919. Crossref

- Hauge, L.J., Einarsen, S., Knardahl, S., Lau, B., Notelaers, G. and Skogstad, A. (2011). Leadership and role stressors as departmental level predictors of workplace bullying. International Journal of Stress Management, 18(4), p.305. Crossref

- House R. J., \& Rizzo, J. R. (1972). Role conflict and ambiguity as critical variables in a model of organizational behavior. Organizational behavior and human performance, 7(3), 467-505. Crossref

- Ilgen, D. R., Hollenbeck, J. R., Johnson, M., \& Jundt, D. (2005). Teams in organizations: From input-process-output models to IMOI models. Annu. Rev. Psychol., 56, 517-543. Crossref

- Ireland, R. and Webb, J. W. (2007). A multi-theoretic perspective on trusts and power in strategic supply chains. Journal of Operations Management, 25(2), 482-497. Crossref

- Jago, A. G. (1982). Leadership: Perspectives in theory and research. Management science, 28(3), 315-336, Crossref

- Jansen, J.J.P., Van den Bosch, F.A.J. and Volberda, H.W. (2005). "Exploratory innovation, exploitative innovation, and ambidexterity: the impact of environmental and organizational antecedents", Schmalenbach Business Review, Vol. 57, pp. 351-363. Crossref

- Jesuit, D. K., \& Sych, L. (2012). Local economic development and cross-border networks. International Journal of Public Sector Management, 25(6/7), 473-482.

- Keegan, A. E. and Den Hartog, D. N. (2004). Transformational leadership in a projectbased environment: a comparative study of the leadership styles of project managers and line managers. International journal of project management, 22(8), 609-617, Crossref

- Kelloway, E. K., Sivanathan, N., Francis, L. and Barling, J. (2005). Poor Leadership. In J. Barling, E. K. Kelloway and M. R. Frone (Eds.), Handbook of Work Stress 89-112. Thousand Oaks, CA: Sage Publications. $\underline{\text { Crossref }}$

- Kirkman, B. L., Lowe, K. B., \& Gibson, C. B. (2006). A quarter century of culture's consequences: A review of empirical research incorporating Hofstede's cultural values framework. Journal of international business studies, 37(3), 285-320. 
- Locke E. A. (1991). The motivation sequence, the motivation hub, and the motivation core. Organizational behavior and human decision processes. Crossref

- Mach, M., Dolan, S., \& Tzafrir, S. (2010). The differential effect of team members' trust on team performance: The mediation role of team cohesion. Journal of Occupational and Organizational Psychology, 83(3), 771-794. Crossref

- Marginson D., \& Ogden, S. (2005). Coping with a mbiguity through the budget: the positive effects of budgetary targets on managers' budgeting behaviours. Accounting, Organizations and Society, 30(5), 435-456. Crossref

- O'Driscoll, M.P. and Beehr, T.A. (1994). Supervisor behaviors, role stressors and uncertainty as predictors of personal outcomes for subordinates. Journal of organizational Behavior, 15(2), pp.141-155. Crossref

- Pearce, C.L., Manz, C.C. and Sims, H.P. (2009). "Is shared leadership the key to team success?", Organizational Dynamics, Vol. 38 No. 3, pp. 234-8, Crossref

- Pearce, J. L. (1981). Bringing some clarity to role ambiguity research. Academy of Management Review, 6(4), 665-674.

- Rhoades L. \& Eisenberger, R. (2002). Perceived organizational support: a review of the literature. Journal of applied psychology, 87(4), 698. Crossref

- Roberts, L. M., Dutton, J. E., Spreitzer, G. M., Heaphy, E. D. and Quinn, R. E. (2005). Composing the reflected best-self portrait: Building pathways for becoming extraordinary in work organizations. Academy of Management Review, 30, 712-736. Crossref

- Rosenthal, R. and DiMatteo, M. R. (2001). Meta-analysis: Recent developments in quantitative methods for literature reviews. Annual Review of Psychology, 52, 59-82. Crossref

- Russo, M. (2012). "Diversity in goal orientation, team performance, and internal team environment", Equality, Diversity and Inclusion: An International Journal, Vol. 31 No. 2, pp. $124-43, \underline{\text { Crossref }}$

- Samuel Sejjaaka, Rachel Mindra, Isa Nsereko (2015). Leadership Traits and Business Sustainability in Ugandan SMEs: A Qualitative Analysis. International Journal of Management Science and Business Administration. Volume 1, Issue 6, May 2015, Pages 42-57, Crossref

- Seifert, D. L., Stammerjohan, W. W., \& Martin, R. B. (2013). Trust, organizational justice, and whistleblowing: A research note. Behavioral Research in Accounting, 26(1), 157-168.

- Skogstad, A., Einarsen, S., Torsheim, T., Aasland, M. S. and Hetland, H. (2007). The destructiveness of laissez-faire leadership behavior. Journal of occupational health psychology, 12(1), 80. Crossref

- Stajkovic, A. D., \& Luthans, F. (1998). Self-efficacy and work-related performance: A meta-analysis. Psychological bulletin, 124(2), 240.

- Van Sell, M., Brief, A. P., and Schuler, R. S. (1981). Role conflict and role ambiguity: Integration of the literature and directions for future research. Human relations, 34(1), 43 71. Crossref

- Yang, I. (2015). Positive effects of laissez-faire leadership: conceptual exploration. Journal of Management Development, 34(10), 1246-1261. Crossref 